\title{
Aspects of advanced foreign language proficiency: Internet-mediated German language play ${ }^{1}$
}

\author{
Julie A. Belz and Jonathon Reinhardt Pennsylvania State University
}

\begin{abstract}
Adult foreign language play has been an under-explored phenomenon in the field of applied linguistics, despite the fact that strong claims have been made about its importance in instructed foreign language learning. This article documents the nature of adult foreign language play in the electronic medium and examines the ways in which computer-mediated communication may afford opportunities for its occurrence. It is further argued that examination of this phenomenon provides insights into issues of advanced foreign language proficiency. The article presents a case study of a 19-year-old American college student who was a participant in a telecollaborative course between the United States and Germany in the fall of 2002. Data are drawn from (a) his course web site, (b) his in-class electronic correspondence with his German keypals, (c) his out-of-class correspondence with these same keypals and his German-speaking girlfriend, (d) his cumulative course portfolio, and (e) focus group interviews.
\end{abstract}

Obgleich Deutsch eine schwere Sprache ist, mag ich sie trotzdem. Deshalb spiele ich damit herum.

'Although German is a difficult language, I still like it. That's why I play around with it'.

[Seamus: 19-year-old English-speaking learner of German, course portfolio, December 17, 2002]

\section{Introduction}

The goals of this paper are two-fold: (a) to document the nature of adult foreign language play at advanced levels of foreign language (FL) proficiency in the electronic medium, and (b) to examine the ways in which computermediated communication $(\mathrm{CmC})$ may afford opportunities for adult foreign language play. In recent years, the construct of 'advanced foreign language proficiency' has begun to attract increased attention in foreign language education circles (e.g. Byrnes and Maxim 2004; Leaver and Shekhtman 2002). Reflexes of this attention are seen, for example, in recent curricular 
developments in the German-language program at Georgetown University (Byrnes 2001) and in the 2002 establishment of the Center for Advanced Language Proficiency Education and Research (CALPER), a federally-funded National Language Resource Center (NLRC) at Pennsylvania State University. Despite this growing interest, the very concept of 'proficiency' remains somewhat vague and, some might argue, ill-defined within the fields of foreign language learning, teaching, and assessment. In fact, Bialystok (1998: 503-4) ranks the definition of 'language proficiency' as the first of three major challenges to the future of applied linguistics research in her contribution to the 50th jubilee issue of Language Learning: "If there is no agreement about what is included in language proficiency, then any explanation that attempts to probe some of the more profound mysteries of language will be incomplete". We contend that detailed documentation and examination of the phenomenon of 'language play' among foreign language learners might afford insights into what it means to be an advanced user of a foreign language (see G. Cook 2000: 150; see Belz 2002d for examples of advanced proficiency as evidenced in language play).

In this article, we focus on the playful linguistic practices of Seamus (a pseudonym), a 19-year-old American college student and an advanced learner of German, in the context of bilingual electronic exchanges in a GermanAmerican telecollaborative partnership. Telecollaboration involves the use of Internet communication tools by internationally dispersed groups of language learners in institutionalized settings for the purposes of foreign language linguistic development and the development of intercultural competence (e.g. Kinginger 2002a; Warschauer 1996). Students in such partnerships typically are paired with expert speakers of the language under study and use e-mail and synchronous chat to discuss a variety of (parallel) texts and to collaborate on common (transatlantic) projects (see e.g. Belz 2002c; Kinginger, Gourvès-Hayward and Simpson 1999; O'Dowd 2003; Müller-Hartmann 2000).

Adult foreign language play (and multilingual or 'hybridized' foreign language play in particular) has been an under-explored phenomenon in the fields of applied linguistics and foreign language learning/teaching (FLL/ $\mathrm{T})$, despite the fact that strong claims have been made about its importance in instructed FLL (e.g. Belz 2002a: 76-7; G. Cook 2000: 204; Lantolf 1997: 19). In an early article on the efficacy of adult foreign language play in the beginning stages of instructed FLL, Lantolf (1997: 10) notes that "precious little" is known about the exact nature of this phenomenon (see Broner and Tarone 2001: 364 for a similar conclusion). Five years later, in an entry in the Oxford Handbook of Applied Linguistics, Lantolf (2002: 108) reiterates his observation that research on adult foreign language play is in its "incipient stages" and adds that the field of applied linguistics could benefit from robust documentation of adult foreign language play (for examples of child foreign language play see Bongartz and Schneider 2003: 18-22, Broner and Tarone 2001, Peck 1980, Saville-Troike 1988; for play-like, multilingual verbal practices among adolescents in Britain see Rampton 1995, 1999). Indeed, the 
first book-length treatment of language play in language learning, Guy Cook's (2000) award-winning Language Learning, Language Play, does not contain a single example of learner-produced foreign language play (either child or adult). Instead, he focuses on the reception of playful language by (child) learners (ibid.: 11) and generally relies on first language (L1) (literary) sources for exemplification of this phenomenon (e.g. Opie and Opie 1955).

One exception to the sparseness of published examples of adult foreign language play has been Belz (1997a,b; 2000; 2002a,b,d; in preparation; also Warner 2004). Among other things, Belz documents and exemplifies that:

a) adult learners play with all levels of the foreign code in creatively resourceful and sophisticated ways (2002d: 221-9);

b) physical aspects of the foreign code such as the sound of shapes and the shape of sounds are particularly amenable to play activities (2002a: 68-72);

c) L1 use is often a mediator of language awareness in learners' multilingual play with the FL rather than the mark of a 'deficient communicator' (2002a: 64-6; 2002d: 223);

d) adult learners' foreign language play frequently involves the resemioticization of the foreign code for locally relevant (and pleasurable) purposes (2002a: 70, 73);

e) adult foreign language play may involve the conscious flouting of FL rituals and conventions (2002b: 33-4).

In the current study, we build on the arguments presented by Belz while extending the published data base of adult foreign language play to include occurrences in the electronic media of chat and e-mail. Previously, scholars investigating computer-mediated FLL have noted the playful nature of some learners' electronic FL interactions (e.g. Honeycutt 2001: 18; von der Emde, Schneider and Kötter 2001: 219), but their interpretations of this phenomenon have been limited. Here we exemplify and describe the ways in which Seamus plays with his foreign language in both chat and e-mail correspondence. We argue that an examination of his play facilitates a characterization of the advanced language learner in terms of both (meta)linguistic knowledge and communicative practices. In general, the types of (meta)linguistic knowledge and practices that are showcased through the activity of language play may not have the opportunity to surface in utilitarian-oriented, correctness-based foreign language classrooms, an arena in which the learner is construed quite often as a rather sad sort of figure, the 'deficient communicator' who is in need of native speaker input and aid (Firth and Wagner 1997; see also Belz 2002a; V. Cook 1999; Leung, Harris, and Rampton 1997).

We also examine various definitions of play and language play, offer our own working definition of the latter phenomenon for the purposes of this study, and look at emerging theories of language play in applied linguistics and its role in FLL. A discussion of the functions of Seamus' foreign language 
play is followed by an interrogation of the ways in which the electronic medium and, most importantly, competence in its use may afford adult foreign language play in ways that participation in traditional classrooms do not (see Belz and Kinginger 2002, 2003 for discussions of broadened discourse options in telecollaboration). We also offer a tentative characterization of some aspects of advanced proficiency based on Seamus' use of foreign language play and conclude with suggestions for further research.

\section{Play and foreign language play}

\section{Definitions}

The "particularly recalcitrant notion" of play (Garvey 1977: 2) has resulted in a proliferation of often contrasting descriptions and wide-ranging definitions (e.g. Cazden 1974: 33; G. Cook 1997: 227, 2000: 123; Chiaro 1992: 5; Ely and McCabe 1994: 21; Huizinga 1949: 33). To illustrate, Vygotsky (1978: 92) cautions that "pleasure cannot be regarded as the defining characteristic of play", while Sullivan (2000: 122) states that "most people would agree play entails fun". Many of these definitions have taken the form of a list of characteristic features or component parts (e.g. Garvey 1977: 4), such as repetition of forms and enjoyment. Caillois (1969), for instance, provides a four-fold division of play into agôn (competition), alea (chance), mimicry (simulation), and ilinx (vertigo), which is qualified by an attitudinal continuum oscillating between ludus, or rule-orientation, and paedia, or "improvisation and gaiety" (G. Cook 2000: 115). The criterial approach to definition underscores the slipperiness of the concept and the ease with which its explanatory power can degenerate into "quibbles over one criterion or another" (G. Cook 2000: 113).

In contrast, other researchers have argued that play cannot be defined in terms of a list of characteristic features. Peck (1980: 154), for example, suggests that "[t]he term 'play' does not refer to a list of activities, but rather to a mode, a way, a manner of doing any activity". Fromberg (1999: 27), to corroborate, asserts that "play is a relative activity that manifests shifting functions in different settings" (italics original). By the same token, Reynolds (1976, cited in Garvey 1977: 5) has described play as "behaviour in the simulative mode". Fry (1963: 125) emphasizes the importance of the player's attitude toward the play activity, i.e. play requires not only simulation of "real world" activity but also the player's realization that the activity is simulative. G. Cook (2000: 101) agrees that affect and player orientation figure prominently in the definition of play: "In fact it is very often . . . attitude which makes something play rather than anything intrinsic to the behaviour per se. People are playing when they say and believe they are playing" (italics original). While this relational approach to definition may avoid the feature-matrix trap of ready and numerous counterexamples to a list of 
definitive necessary and sufficient characteristics, it leaves one with the rather dissatisfying impression that "anything goes", i.e. that play can be anything at all. (See Belz 2001a: 132 for the suggestion that play may be conceptualized best as a pluricentric radial category in the Lakoffian [1987] sense.)

In this article, we opt for a learner-sensitive yet form-based definition whereby language play is "the conscious repetition or modification of linguistic forms such as lexemes or syntactic patterns" (Belz 2002b: 16; see also Kuczaj 1983: 3-9; Weir 1962: 80-3). ${ }^{2}$ To use a musical metaphor, language play is similar to variations on a theme. In order to create a variation of a musical theme, one first must be keenly aware of the rules of patterning and sequentiality in the original musical score. It should be clear that language play, as such, involves a fundamental tension between forces of convention and creativity (Belz 2002b: 16, 24; see also Lantolf and Yáñez 2003: 100).

\section{Foreign language play and foreign language learning}

The first to propose a theory of (adult) foreign language play in instructed FLL was Lantolf (1997). ${ }^{3}$ His focus is on the ways in which adult foreign language play may facilitate the development of FL forms in the learner. For Lantolf, language play is a function of private speech, i.e. speech directed at the self, which, in turn, figures prominently in the process of internalization, an essential but under-examined construct (Vygotsky 1978: 57) in sociocultural approaches to FLL (e.g. Lantolf and Appel 1994). According to Vygotsky, private speech is critical to internalization, the process whereby elements of the child's (and, by way of extension, the learner's) inter-mental sociocultural world become part of his intra-mental private world; the process by which "we talk ourselves into knowledge" (Lantolf 2000b: 4). The learning of FL forms, which the learner first encounters "out there" in the interpsychological plane, represents one example of internalization, i.e. knowledge moving from "out there" to "in here". In relation to the role of language play in the internalization of FL forms, Lantolf (2000b: 6) believes that "it is the play function of private speech that facilitates L2 (second language) learning and may even be L2 learning 'in flight' ..." (see John-Steiner and Tatter 1983 for other functions of private speech). For Lantolf (1997: 11), language play may take the following forms: ". . talking out loud to yourself in [the FL]; repeating phrases to yourself silently; making up sentences or words in [the FL]; imitating to yourself sounds in [the FL]; having random snatches of [the FL] pop into your head", and it is imitative in nature (Lantolf 2000b: 7). However, imitation in the Vygotskian sense does not entail the mere aping of the words of others, but, crucially, is transformative in conceptualization (Frawley 1997: 94-5; Kinginger 2002b; Tomasello 1999: 26).

Based on MacWhinney's (1985) competition model and Swain's (1995) "pushed output" hypothesis, Lantolf (1997: 15-7) proposes how private language play may function in the acquisition of L2 forms. In short, Lantolf 
suggests in his dialectic model that the thesis is what the learner assumes to be the case (e.g. an incorrect FL form), while the antithesis is what the learner notices is actually the case (e.g. a correct FL form). Language play is the work that the learner may carry out on the system in order to restore equilibrium and produce the synthesis, i.e. the correct FL form; it is an "enlightened" comparison of the old system (thesis) with the new system (antithesis) based on a learner-perceived mismatch between the two. In this way, Lantolf's notion of language play seems to be in line with relational definitions of play in general in the developmental and educational literature.

In a later article, Tarone (2000: 44) claims that ludic language play ${ }^{4}$, i.e. play for the purposes of fun and amusement, is not necessary for FLL; however, for those learners who do engage in it, it may serve four functions. First, ludic language play may lower the learner's affective filter (Krashen 1981) and thus facilitate FLL. Second, the positive affective state created by ludic language play may increase the memorability of the bits of language associated with this state (see also G. Cook 2000: 169-70 for a similar suggestion). This line of argumentation is reprised in Broner and Tarone (2001: 375) when these authors write that ludic language play may account for an "adrenaline rush" in the learner whereby "the emotional excitement that comes with language play may simply make the L2 discourse more noticeable, and thus more memorable...". Next, Tarone (2000: 46) notes that semantic ludic language play, i.e. "play with units of meaning, combining them in ways which create worlds which do not exist: fictions" (G. Cook 1997: 228), may facilitate the learner's acquisition of multiple FL registers. The final and most important function of ludic language play in Tarone's discussion is the contribution that it may make to the destabilization of the learner's interlanguage (IL) system (see Broner and Tarone 2001: 375 for a reiteration of this argument). Tarone (2000: 47-50) argues that ludic language play frequently results in the production of multiple (often incorrect) variants of expected FL forms. Such variants represent the injection of unpredictable, random elements into the learner's IL system, which promote both its maintenance and its evolution (Tarone and Liu 1995). In summary, both Lantolf (1997) and Tarone (2000) stress the ways in which foreign language play may aid in the development of FL forms (although each author readily supports the multifunctionality of this phenomenon).

\section{Multilingual foreign language play as an index of multicompetence}

Belz's work (1997a,b; 2000; 2002a,b,d) with adult learners' multilingual foreign language play in the written medium offers a different (although by no means mutually exclusive) interpretation of adult foreign language play in FLL/T that focuses, in particular, on the link between adult foreign language play and learner "identity transitioning" at advanced levels of FL instruction (Belz 2002d: 221; see also Kinginger 2004 for "renegotiated 
identities" in FLL). Unlike Lantolf $(1997,2000)$ and Tarone (2000), Belz does not emphasize the role that adult foreign language play may assume in the acquisition of FL forms; instead, she focuses on what this phenomenon might reveal about "the interactional, social, and local dimensions of language learning from the perspective of the learner" (Belz 2002a: 61). Furthermore, while Lantolf and Tarone appear to zero in on the role(s) of foreign language play as a mediator of the internalization of FL forms (or registers), Belz considers the ways in which this same phenomenon may serve as an externalization of the learner's growing multicompetence, i.e. the "state of mind with two grammars" (V. Cook 1991: 121; see also V. Cook 1992, 1995), a state of affairs that has been afforded through foreign language study. This consideration is underpinned by a representational (Widdowson 1992: 16-25) or semiotic view of linguistic form (Halliday 1978, 1994) whereby "grammar is a theory of human experience" (Halliday 1990, cited in Kramsch 1993: 8) such that a speaker's attitudes, values, and beliefs, indeed, their very identities are embedded and displayed in the language that they use (Gee 1999: 30; see also Ivanic 1998). According to this view, foreign language play - and multilingual foreign language play in particular - may function not only as a sign of how the FL is "going in", but also as an externalized index (in the medium of language) of what the learner has already learned and how he or she has been changed in this process of FL internalization.

Such change is nowhere more evident than in learners' multilingual or hybridized play with language names. For example, Anu, an 18-year-old Gujarati- and English-speaking learner of German, modifies and thus plays with the syllable structure of the words English and Deutsch in order to create the hybridized language name Engleutsch. In metalingual commentary on this instance of foreign language play, Anu refers to Engleutsch as "meine eigene Sprache" 'my very own language' and later adds that her ability to communicate in Engleutsch has become her "pride and joy" (Belz 2002b: 23). Similarly, the form-based play of Al, a 21-year-old Englishspeaking learner of German, with the verb-second constraint in the syntax of modern German functions as a prideful display of his previous internalization of this German grammar rule and simultaneously announces his informed ability to flout the norms of the language he has mastered (Belz 2002b: 28-32).

By using language play to create new and linguistically hybrid names for the languages that they speak or by skillfully flouting FL syntactic rules, foreign language learners are producing textual icons (Belz 2002b: 32) for the new multicompetent modes of being that they may inhabit as a result of foreign language study. In this way, they are re-voicing the words of others in the Bakhtinian (1981: 189) sense, but not necessarily in order to approximate FL norms with respect to register as Tarone (2000; see also Broner and Tarone 2001: 375) has suggested, but rather to distinguish themselves as "richly textured practitioners" (Belz 2002a: 77) in a multilingual "galaxy of signifiers" (Barthes 1974: 6) for locally relevant purposes. 
Belz's research on multilingual foreign language play further distinguishes itself from the work of both Lantolf and Tarone with respect to the type of data examined. Lantolf (1997) bases his work on learner surveys (rather than actual instances of learner-produced foreign language play) and previously published data (e.g. Saville-Troike 1988; see, however, Lantolf and Yáñez 2003). Tarone (2000: 35-44) surveys 25 years of previously published scholarship for instances of what she interprets to be language play, while Broner and Tarone (2001) provide examples of verbal language play in the classroom discourse of 11-year-old children. Belz, on the other hand, documents an extensive collection of learner-produced (multilingual) adult foreign language play for 30 advanced learners of German (ranging in age from 18 to 32 years) in the print medium (see also Ohta 2001 for the verbal play of adult learners of Japanese). The emic (or learner-conscious) aspect of foreign language play is underscored in her research by the use of recall protocols in which these foreign language users are interviewed and asked to comment on instances of foreign language play in their discourse.

\section{The study}

\section{Project and course description}

The data, which are presented here in their original, unaltered form, were produced by our focal student, Seamus, in the context of a fourth-semester German course at a major public institution in the United States. This course represents the first FL elective beyond the institution's three-semester FL requirement. The particular class under study was part of a larger, federallyfunded, cross-linguistic research project designed to investigate the influence of telecollaboration on the instructed learning of French, German, and Spanish at the college level in the USA. From 2000 to 2002, an intermediate FL class in each of these languages was electronically paired with an EFL class in a country where the language under study is spoken natively (the experimental section), whereas the students in the control sections did not have the opportunity to telecollaborate with expert-speaking users of their respective FLs.

As a result of the misalignment of the American and European academic calendars, telecollaboration between the two groups was not possible for the entire 15-week semester but rather only for an 8-week period. In the time leading up to the telecollaborative period, each student in the US group prepared a web-based autobiography that was intended to serve as a personal introduction for their German partners. Based on their examinations of these web-biographies, the German students chose an American keypal with whom they were to correspond electronically over the course of the 8-week partnership. Thus, for the Americans, the design and presentation of the web-biography was a high-stakes assignment which might exert considerable influence on the shape of their pending electronic exchanges. 
Telecollaboration was divided into three phases. In the first phase, the newly partnered transatlantic keypals became acquainted with one another through a series of teacher-guided tasks. One of these tasks involved filling out an online questionnaire which dealt with a series of culturallycontingent vignettes and situations (the cultural survey; see Furstenberg et al. 2001). The US students read and responded to the questionnaire in English, while the German students read and responded to a German version of the same questionnaire. Responses were automatically posted to the Internet so that all students in both countries could examine all answers to the questionnaire in both languages. Using the client-based teleconferencing program FirstClass, keypals employed both e-mail and synchronous chat in order to discuss similarities and differences in responses to the cultural survey with one another. FirstClass was installed in open-access university computer labs and technology classrooms in both the USA and Germany; furthermore, students could download the program free of charge to their home computers via the Internet if they so desired. In addition, keypals had the opportunity to write to their partners on topics of their choice or on topics related to the Americans' presentation of self in their webbiographies. In all cases, students were instructed to conduct roughly half of their correspondence in English and half in German (for similar arrangements, see Appel 1999; Kötter 2003) in order to practice their respective L2s and to provide their keypals with models of L1 use.

The questions on the cultural survey were based on themes from two sets of parallel texts, the discussion of which formed the second phase of the telecollaborative partnership. Parallel texts examine the same topic or theme but in different languages. For example, both groups of students read the German-language children's novel Ben liebt Anna (Härtling 1997) and the English-language juvenile novel If You Come Softly (Woodson 1998), which deal with first love between an inter-ethnic and an inter-racial couple, respectively. Under the guidance of their instructors, keypals electronically discussed their varying reactions to these texts as well as the culturally specific construction of text-related concepts such as 'foreigner' and 'beauty'. In the final phase of the partnership, keypals worked in transatlantic groups of three to five students in order to design and post a website focusing on a topic that arose in the course of their engagement with the cultural survey or the parallel texts (e.g. a project on literary censorship grew out of a comparison of the German original and the English translation [Härtling 1990] of Ben liebt Anna).

The US German course met Mondays through Thursdays for 50 minutes each day, whereas the German seminar met on Thursdays for 90 minutes. On Tuesdays and Thursdays the US group met in a computer laboratory in order to read e-mails from their partners, compose e-mails, and/or work on their web projects. Ideally, partner classes should be scheduled so that they overlap temporally at least once a week in order to enable in-class synchronous chat (Belz and Müller-Hartmann 2002: 76), a mode of 
communication that affords language learning opportunities different from those of asynchronous e-mail exchanges. In the fall of 2002, scheduling difficulties prevented temporal overlap between the courses under study. Therefore, it was not possible for keypals to chat regularly during class time; ${ }^{5}$ however, many of the students in this course were already proficient members of computer-mediated discourse $(\mathrm{CmD})$ communities (Herring 2003; Paolillo 1999; Wellman and Gulia 1999) in which they frequently used the free online chat service AIM (AOL Instant Messenger) to communicate with age peers and family. Thus, these students readily co-opted this home activity into their institutionalized learning of German in order to correspond outside of class time with their new German keypals (see Thorne 2003: 54-6 for the similar case of Oliver and Kirsten).

\section{Participants}

In this section we describe Seamus' psychobiography (Layder 1993) with respect to FLL and electronically-mediated interaction. Layder (1993) argues that in order to more fully understand any type of social action (such as participation in telecollaboration), it is imperative to take into account an individual's socio-cultural history.

Seamus was one of 11 students who participated in the experimental German section during the fall of 2002. His German class was partnered with a seminar of German-speaking students of English who were studying at a teachers' college in Germany in order to become English teachers at the elementary or secondary levels in the German educational system. The students in the US course were pursuing various undergraduate degrees, although many of them had German as a minor subject.

At the time of his participation in the telecollaborative course, Seamus was in his second year of university study. His career goal was "to become a German instructor" because foreign languages were "the only academic interest" he had ever had (biographical survey). Initially, Seamus was enrolled in the control section of the course, but when he learned that another German class would be corresponding electronically with Germans, he became "jealous" and decided to "give up an hour of sleep" in order to switch into the telecollaborative section (interview).

Seamus was born and grew up in a rural area of the USA. Despite his keen interest in foreign languages, nurtured by a "very encouraging" high school German teacher (interview), Seamus has not had much opportunity to interact with individuals from other cultures. He describes his social milieu both at home and during his first semesters at college as "pretty much [the] same old white people... [with] everybody speaking English" (interview). Thus, for a student from an ethnically and linguistically homogenous rural community within the USA, telecollaboration with a German represented a novel opportunity to interact with a person from another 
culture. In his last year of high school, Seamus did participate in a German American Partnership Program (GAPP) exchange during which he spent three weeks in Germany. While there, Seamus made several German friends, including his German-speaking girlfriend, Astrid. At the time of his participation in the telecollaborative course under study, he was chatting with her daily, although she was not a member of the class.

Like many of his generation, Seamus appeared to be proficient at computer-mediated discourse and was an active participant in $\mathrm{CmD}$ communities. On the technological survey, he strongly agreed with the statements that he was comfortable with computer technology and that learning to use a computer to communicate with others is an important real-world skill. When asked in his interview how many hours per day he uses a computer, he responded by saying "I don't know. Man! I waste a lot of time on that thing". Seamus' first computer experiences came at the age of 13 when his parents bought a personal computer. He describes one period of heavy Internet use in high school, when he had as many as 80 keypals on his AIM "buddy list", in the following way: "I used to talk to, like, tons of people I didn't know and just be silly because it didn't matter, you know, who when are you ever going to see them? You could just be silly and say whatever you want." This quote indicates the extent of Seamus' socialization into $\mathrm{CmD}$ communities prior to his participation in telecollaboration. Seamus regularly incorporated his proficiency in $\mathrm{CmD}$ communities into his institutionalized learning of German. In several instances, he used AIM during class time to correspond with his German keypals. On a number of occasions, he chatted with his girlfriend Astrid in an AIM window while composing an e-mail in a FirstClass window to one of his class keypals. In these cases, he frequently asked Astrid for help (via AIM) in the composition of his e-mails in FirstClass.

\section{Data sources}

The playful episodes examined below derive primarily from three sources: (a) Seamus' web-biography, (b) his in-class correspondence with his German keypals using FirstClass, and (c) his out-of-class correspondence with the same keypals using AIM. In the latter case, he voluntarily saved electronic transcripts of these chats and archived them in his group folder in FirstClass. In addition, Seamus presented and discussed excerpts from his out-ofclass personal chats with his German-speaking girlfriend in his end-of-thesemester course portfolio. These excerpts contain valuable examples of naturally occurring adult foreign language play in the context of private conversation between intimates. Prior to the onset of telecollaboration, Seamus provided data in the form of an online biographical and technological survey, an L2 writing diagnostic, the Cross-Cultural Adaptability Inventory (CCAI), the Beliefs About Language Learning Inventory (BALLI) and the 
Contextualized Speaking Assessment (CoSA) of the Minnesota Language Proficiency Assessments (MLPA). These latter four measures were administered to Seamus again at the end of telecollaboration. In addition, he participated in a focus group interview with both authors and another student from the experimental section immediately after the conclusion of the telecollaborative partnership.

\section{Data}

\section{Play with word formation}

Seamus' electronic correspondence includes examples of foreign language play that reflect his knowledge of the rules of derivational morphology in German.

\section{Play with derivation}

Example 1 is taken from Seamus' first chat with his German keypal, Katerine. At one point in their chat, Katerine does not respond for some time, which prompts Seamus to write the following lines:

1) 1 Seamus: schreib was du langsamerin!

'write something, you female slow-y!'

2 Seamus: haah

3 Seamus: manchmal erfinde ich worter

'sometimes I invent words'

[chat in FirstClass; November 5, 2002]

In this excerpt, Seamus nominalizes the adjective langsam 'slow' by suffixing the morphemes -er and -in to produce the neologism langsamerin 'female slow- $y^{\prime}$. In Modern German, the suffix -in is used to derive feminine nouns from masculine ones and the suffix -er generally is used to derive nominal agents from verbal bases. It is not used, as Seamus uses it here, to derive nouns from adjectives (Durrell 2002: 498). Seamus signals an awareness of the non-standard nature of langsamerin when he tells Katerine in line 3 that he sometimes invents words. In his post-semester interview, he explained that he knows langsamerin is not a word in German but that he used it in his chat with Katerine anyway because, in his opinion, it described her perfectly (and better than any other word) in the given context at that particular moment in time. In $\mathrm{CmD}$ communities, chatters who do not respond quickly enough are often referred to as 'sleeping'. Thus, in his impromptu invention of langsamerin, Seamus combined (a) his knowledge of communicative norms in $\mathrm{CmC}$, and (b) his knowledge of German derivational rules in order 
to produce a new and pragmatically hybrid linguistic sign. During his interview, Seamus explained that he could have used the English word slowpoke to express the idea that he wanted to convey, but that, in his opinion, langsamerin was better. Seamus' preference for this word may be motivated by those qualities of using German that he loves, one of which is "changing the way words can be used" via morphological derivation. He said that he enjoys using "endings and things" to create his own "fictional German words". This was illustrated when he produced the word Tischleinlichkeit 'the state of little table-ness' on the spot, also displaying his advanced awareness of both the semantics and sequencing of derivational morphology in German.

Later in the same chat, Katerine echoes (and thereby legitimates) Seamus' practice of word creation when she calls him Langsamer 'male slowy'. She explains to Seamus that she, too, can invent words. In his interview, Seamus notes that Katerine's play with the word Langsamer gave him "a very cool impression of her". The object of Seamus' positive evaluation does not appear to be Katerine's ability to convey (unique) ideational content via wordformation but rather her ability to engage in the same type of linguistically playful repartee in which he engages.

In the next example, Seamus applies a similar derivational strategy, i.e. the suffixation of the morpheme $-i n$, in order to create what he perceives to be another new word in German. His lexical creativity does not elicit the same response from his keypal in this case, however. Instead, it appears to function, at least from Katerine's perspective, as a linguistic threat that serves to assault her sense of positive face, i.e. her desire to be liked and respected by others (Brown and Levinson 1987; Simpson 1997):

2) 1 Seamus ich muss jezt weggehen, wir wandern!

'I have to go now, we're going for a walk!'

2 Seamus: ok du hundin!

'ok, you female dog!'

3 Seamus: ??

4 Katerine: Ok, it's time for a young lady to get ready for a Saturday night anyways. Hope you have fun. Was surely nice talking to you!!! Until you called me Hündin...

5 Seamus: haha

6 Seamus: $d u$ heisst hund

'your name is hund'

7 Seamus: $\quad$ und bist weiblich

'and you are female'

[chat in FirstClass; November 5, 2002]

After making a conversational bid for closing the chat in line 1, Seamus creates what he considers to be a new word by adding -in to the noun Hund 'dog' (Katerine's last name ${ }^{6}$ ) and uses it to address Katerine in combination with the informal pronoun of address, $d u$ (Delisle 1986). He does not, 
however, add an umlaut to the nominal base, which typically co-occurs with -in derivation in Modern German (Durrell 2002: 499; Drosdowski 1984: 462). There is a subsequent pause in the chat, which prompts Seamus to question why Katerine is not responding to his address (??). Katerine then gives a terse response which may leave Seamus to wonder if his word play missed the mark, as the scriptualized laughter (haha) and quick explanation testify (lines 6-7). In his interview, Seamus explained that he intended to make a play on Katerine's last name and added that "it probably doesn't mean 'bitch' like the way we mean bitch". When we explained that it does, in fact, have similar connotations, especially for someone who is familiar with the English meaning, Seamus was surprised. He thought it unusual that Katerine would use an umlaut (i.e. Hündin) in her own last name if this were the meaning, and maintained that his omission of an umlaut should have conveyed to her that he did not intentionally call her a bitch.

Example 3 is a segment from an annotated AIM transcript that Seamus placed in his course portfolio in order to illustrate his play with his favorite German morphemes, the derivational suffixes -heit and -keit. In the AIM transcript in question, Seamus and Astrid are discussing why Astrid has not yet bought Seamus a Christmas present:

3) 1 Astrid: aber ich glaub nicht dass es bei mir faulheit ist

'but I don't think its because of laziness on my part'
Seamus: armheit?

$$
\text { 'poor-ness?' }
$$

3 Seamus: keinelustheit?

'no-desire-ness?'

4 Astrid: nein weihnachtsblödigkeit

'no, Christmas-stupidity'

5 Seamus: haha

6 Seamus: ja, ich stimme dir $z u$

'yes, I agree with you'

[portfolio; December 17, 2002]

In Modern German, the suffix -heit and its allomorphs, -keit and -igkeit, are used quite productively to derive abstract nouns from adjectives. In line 1, Astrid discounts faulheit 'laziness' (capitalized in standard orthography but uncapitalized in the present chat, reflecting the norms of $\mathrm{CmC}$; see Danet, Ruedenberg and Rosenbaum-Tamari 1998: 46) as the reason why she has not yet bought Seamus a Christmas present. In line 2, Seamus suggests armheit 'the state of being poor, poverty' as an alternative explanation for Astrid's disinterest in Christmas shopping. In order to form this word, he mimics the derivation of faulheit by suffixing -heit to the adjective arm 'poor'. In Modern German, however, the conventional word for 'poverty' is Armut, not armheit. In line 3, Seamus uses the complex nonce formation keinelustheit in order to express the state of 'not wanting to do something' as another reason for 
why Astrid has not yet completed her Christmas shopping. It should be noted that the words Unlust 'reluctance' and Unlustigkeit 'lack of enthusiasm' are available in German for the expression of this meaning. Finally, in line 4, Astrid joins in on the morphological fun and creates the word weihnachtsblödigkeit 'Christmas-stupidity' as another possible reason for why she has not yet done her Christmas shopping.

From the morphological and semantic perspectives, it appears that Astrid and Seamus played quite cleverly with -heit suffixation in German in order to create situationally appropriate words in the context of their chat. They appear to be engaged in a type of verbal duel that involves upping the syllabic ante in each successive turn (see G. Cook 2000: 64-7; Gossen 1976).

\section{Play with nominal compounding}

In example 4, Seamus explains that he likes the way in which German words can combine with one another to create new words. He calls this process "a really cool word puzzle". He gives an example of a nominal compound that he created in order to refer to his German girlfriend Astrid (who is not a member of the class).

4) Etwas anderes was ich cool finde, ist die Art und Weise, wie deutsche Wörter miteinander verbindet werden können. Die neu entstandenen Wörter klingen cool, und vielleicht mag ich auch das Aussehen. Also erfinde ich auch verbundene Wörter. Meistens sind es Wörter, wie ich meine Freundin nenne: wo bist du denn, lieblingsverlobungsmachdingleinschlampechen??????????

'Something else I find cool is the way that German words can be compounded together with each other. The new words sound cool, and maybe I also like their appearance. So I also make compound words. Usually they are words that I call my girlfriend: where are you, lovelyengagement-make-thinglet-tramp-kin?'

[portfolio; December 17, 2002]

In this excerpt, Seamus states that his attraction to nominal compounding in German is related not so much to the opportunities it affords for semantic expansion (Drosdowski 1984: 401), but rather to the sound of the compounds and to the way that they look, i.e. to the visual shape of the sign.

The allure of the physicality of the compound for Seamus is similar to the response that $\mathrm{Chris}^{7}$ has to the visual impression of the Eszett [ $[1$ ], a letter in Modern German orthography (Belz 2002a: 69-70). Chris re-semiotizes this grapheme as a textual icon for her own personal meanings when she reports in an interview that the visual tangle of the Eszett represents the way that she feels when she experiences the state of physical and emotional hardship generally referred to as stress. 
Example 5 is also taken from an entry in Seamus' course portfolio in which he annotates excerpts from a private chat with his girlfriend, Astrid.

5) 1 Seamus: bis bald, lieblingsverlobungsfrauuuuuuuuuuuuuuschlampeschwesterzwillingsding

'until soon, dear-engagement-womaaaaaaan-tramp-sistertwin-thing'

2 Meine Freundin nimmt manchmal auch teil:

'my girlfriend also takes part [in the creative production of nominal compounds] sometimes'

3 Astrid: gute nacht verlobungsverrückterlieblingsmacher

'good night engagement-crazy-dear-maker'

4 Für die meisten anderen Leuten machen diese erfundenen Wörter keinene Sinn, aber für uns schon!

'For most other people these invented words make no sense, but they do for us!'

[portfolio; December 17, 2002]

In line 1, Seamus exemplifies how he closes a chat with his girlfriend by creating a new name for her that consists of seven compounded German nouns as well as letter repetition (see below). He then comments in line 2 that she sometimes reciprocates his playful strategy of compounded naming by providing an example of a name that she created to refer to him. Again, Seamus does not appear to focus on the semantic comprehensibility of the words that he creates (or their potential acceptability in the traditional language classroom), as he notes in line 4 . Instead, he seems more attuned to the physicality of these newly created signs, the pleasure that he derives from both their creation and their use, and the (ritualized) role that they play in the performance of electronically-mediated conversation with his girlfriend.

\section{Play with letters}

Seamus chose and posted the word Kurzbiographiiiieeeeeeeeee as the title of his web-biography. With his repetition of the letters $i$ and $e$, Seamus created a play on the word Kurzbiographie 'short biography', which was the name of this graded class assignment. Seamus explained that he "was being silly and goofy" with his use of the word Kurzbiographiiiieeeeeeeeee and that his purpose in choosing it as the title of his web-biography was to "lighten it up a little".

Seamus also used letter repetition in several e-mails to his keypals over the course of the telecollaborative project. For example, he repeated the letter $s$ in the word spass 'fun' in the closing of one message: "jetzt gehe ich in astronomie viel spasssssss" ('now I'm going to astronomy class, (have) fun'). He similarly repeated letters in the words tschüß 'good-bye' (which he 
wrote with neither an umlaut nor an Eszett) and alle 'everyone' in the closing of another e-mail: "Tschuuuuuuuussssss alleeeeeeeee" ('good-bye everyone'). In his interview, Seamus explained that these orthographic repetitions were designed "to be silly and make it a friendly, stupid end to an e-mail". He also noted that he "sometimes does it in English" and performed the word hello with elongated stress on the final syllable as an example. Seamus displayed an awareness of the situated meanings (Gee 1999: 80) of letter repetition and elongated syllabic stress when he related that he uses such words "just [with] my friends - I don't, like, write the dean of the university and say goodbye [elongated stress on bye] ... because it's an informal thing".

In contrast to his use of letter repetition in the title of his web-biography and in e-mail closings, Seamus occasionally repeated letters in the context of chats with his keypals for a different reason. For example, in one message he repeated the $a$ in the word blah ("blaaaaaaaaaaaaaaaah"), and on more than one occasion Seamus typed repetitive strings of letters that amounted to nonsense words, e.g. sedafdsfsdfdsf. When interviewed, Seamus explained that these words represented "frustration kinds of words".

\section{Re-voicings of salient bits of language}

In example 6, Seamus is chatting with his German keypal, Katerine. When she doesn't respond for a while, he "calls out" to her by using the word schlafmutze 'sleepy-head', written as Schlafmütze in standard German orthography:

6) 1 Seamus: Hey, schlafmutze

'Hey sleepyhead'

2 Seamus: schlaefst du?

'are you sleeping?'

[chat; November 2, 2002]

In his interview, Seamus explained that he had learned this word from Härtling's (1997) novel, Ben liebt Anna, one of the parallel texts read in the telecollaborative project. In the novel, this word is addressed to the protagonist, 9-year-old Ben, by his 13-year-old brother Holger in a rare moment of friendly and playful fraternal repartee. By appropriating this word for use in computer-mediated discourse where 'sleeping' refers to a delay in response, Seamus creates a sort of 'interlingual' intertextuality between the reading materials in his German course and his experiences in $\mathrm{CmD}$ communities (for other examples of hybrid language play, see Belz 2002a,b,d; for linguistic hybridity and literacy in bilingual education, see Gutiérrez, Baquedano-López and Tejeda 1999; Gutiérrez, Baquedano-López and Álvarez 2001; see also Nilsen 1981).

In example 7, Seamus re-voices a phrase that he had learned in Germany in a chat with Katerine: 
7) 1 Katerine: See, I totally messed up my sentence because of you.

2 Seamus: schade marmelade

'too bad, marmelade'

[chat; November 2, 2002]

When Katerine accuses Seamus of causing her mistake in a previous posting (not shown), he responds with the playful, sarcastic rhyme schade marmalade (word-final $-e$ is not silent in German but pronounced as an unstressed mid-vowel), which means something along the lines of 'poor baby'. In his interview, Seamus explained that he had learned this phrase by repeating his German exchange brother's use of it "in front of a bunch of German people [who] all thought it was really funny". Thus, Seamus' use of this phrase in chat with Katerine may function as a re-voicing of a previous episode where he had achieved positive face with its use (see Belz 2002b: 68 for a different type of re-voicing). He may have been hoping for a similar response from Katerine.

\section{Discussion}

\section{Functions of Seamus' foreign language play}

Foreign language play as a vehicle for a pleasurable activity

In his interview and in his course portfolio, Seamus repeatedly acknowledges that he derives pleasure from "playing around" with German. For example, in his portfolio, in reference to his production of langsamerin, he writes "ich liebe, dass man Nomen aus Adjektive machen kann" ('I love it, that one can make nouns out of adjectives'). He "loves" the way Tischleinlichkeit sounds; he thinks that nominal compounding is "cool"; he repeats letters in order to be "silly and goofy"; he describes "changing the way words can be used" as a kind of game that is "fun", "creative", and "inventive"; and he remembers the phrase schade marmalade because a group of Germans thought that it was "really funny" when he said it once in front of them (see Tarone 2001: 375).

While some facets of the pleasure that Seamus derives from playing around with German may be related to the ways in which his newly created forms function on the interpersonal level, other aspects are more explicitly related to the physical properties of the language itself. In his focus on the physicality of German, Seamus appears to foreground the palpability of the linguistic sign as an object of play and, subsequently, as a source of pleasure: he likes the way that his invented nominal compounds sound, but he also likes the way that they look (see Belz 2002b: 68-73; Jakobson and Waugh 1987). In at least one instance, Seamus associates computer-mediated foreign language play with the actual tactile processes that he employs in its fabrication. He 
explains that he produces forms such as Kurzbiographiiiieeeeeeeeee not by repeatedly striking individual computer keys (the conventional method of typing) but by holding down particular keys for a certain length of time, much like one would hold down the keys of a piano in order to produce a sustained sound (see Danet et al. 1998: 42). This potentially rhythmic quality of language production may contribute to what some have referred to as the "flow" experience in CmC (e.g. Danet et al. 1998: 45; Thorne 2003: 51-3). Seamus thus appears to foreground the palpability of the computer keyboard itself, the mediator of his correspondence with both Katerine and Astrid. His elongated words are textual icons of actual, physical play.

\section{Foreign language play and grammar}

Seamus' foreign language play may function in some cases as a means of learning new and unfamiliar aspects of German (Lantolf 1997). For example, in his cumulative course portfolio, he reports on a chat with Katerine in which he learned the vocabulary item schüchtern 'shy'. After first inappropriately writing schuschtern, Seamus asked Katerine "habe ich das erfunden?" ('did I invent that?'). Katerine immediately responded by stating "it's 'schüchtern'". Seamus explained in his portfolio that this example "zeigt einen beiläufigen Lernprozess" ('illustrates an ancillary learning process') that took place in the course of his telecollaborative correspondence with his German partners: he learned a new vocabulary item. According to Seamus, "seitdem habe ich 'schüchtern' immer richtig geschrieben" ('since then I have always written "shy" correctly') (see Belz and Kinginger 2002 for the relationship between peer-assisted noticing and language learning in telecollaboration). It is important to note that Seamus uses the term erfunden 'invented' to refer to his production of schuschtern. This is the same term that he uses to describe other instances of word-formation which are explicitly labeled as language play.

Seamus' foreign language play may also function as a method whereby he consolidates aspects of German grammar with which he is already familiar. Belz (2002a: 31) reports the cases of Lin and Kim, two English-speaking learners of German, who play with the placement of the finite verb in the German main clause, an aspect of L2 syntax which is familiar to them but nonetheless problematic (see also Chiaro 1992: 40-3 for play with syntax). In the case of Seamus, his play with derivational morphology may be a way of testing out the limits of particular patterns and rules (Tarone 2000). He is aware, for example, that the suffix -in means 'female' when he creates the term hundin to refer to Katerine. He is unaware, however, that this appellation is inappropriate as a nickname for his female partner. Thus, his production and subsequent use of it may function as a type of playful linguistic experimentation designed to explore the boundaries of -in derivation in German. Exploratory language play of this nature is reminiscent of what 
Halliday (1993: 97) refers to as a "trailer" in the process of first language learning. A trailer is "a kind of preview of what is going to come. Children take a new step forward, and leave a footprint as it were, showing that they have been there; but then back off for a while before consolidating this step and building it into the overall learning process."

Seamus' creation of langsamerin may be an attempt to explore the productivity of -er suffixation under the electronic mentorship of an expertspeaking interlocutor. Indeed, Seamus may also draw on Astrid's expert competence through his electronically mediated foreign language play in order to both increase and consolidate his knowledge of German grammar. For example, the question marks after armheit and keinelustheit in excerpt (3) may function additionally as requests for confirmation of both the semantic appropriateness and morphological well-formedness of these terms.

Foreign language play as a vehicle for linguistic creativity

According to Fowler (1996: 55),

any activity is creative which is capable, under the right conditions of production and reception, of reanalyzing people's theory of the way the world works ... Often this questioning of existing conventions is the basic creative act that is being performed....

Language play, we recall, involves the conscious repetition or modification of linguistic forms. As such, it is an inherently creative act because it requires knowledge of linguistic convention and some type of alternative perspective on that convention. Learners may "play around" with foreign linguistic forms in order to try to get the forms right (Lantolf 1997). At advanced levels, learners may do this with previously learned linguistic forms in order to create new forms, forms that they like. ${ }^{8}$ In the first case, language play may be experienced as pleasurable based on the type of satisfaction that one feels when one finally "gets it right" and successfully internalizes a foreign language form. In the second case, language play may be experienced as pleasurable based on the feelings of pride and accomplishment that one encounters in the creation of something new and unique (see Belz 2002b: 28-32). Thus, Seamus may be attracted to foreign language play and engage in it so frequently because he is hooked on the thrill of linguistic creativity. This seems to be the case in his fabrication of both langsamerin and Tischleinlichkeit. Seamus must know the meaning and sequencing of the suffixes $-e r$ and $-i n$ in order to create langsamerin; he realizes that he is bucking linguistic convention in its production, however, although he may not be able to articulate why (i.e. adjectives do not serve as bases for agentive -er suffixation); but he uses it anyway in a chat with Katerine. He uses it because he likes it, and he likes it because it is his own. This sense of ownership may be enhanced by 
the fact that in order to get to the point in his learning of German where he can produce words like langsamerin, Seamus had to work hard to develop the knowledge of German morphology that is necessary to creatively and successfully flout it. In the case of Tischleinlichkeit, Seamus also displays an advanced knowledge of both the meaning and sequencing of derivational suffixes in German. He is enthusiastic about his production of this form precisely because it does not exist in German - because it is a unique and "cool-sounding" word that he has created on his own based on his advanced knowledge of German.

\section{Foreign language play as a means of personal relationship building}

G. Cook (2000: 68) argues that private and personal environments such as storytelling in the home and conversation between intimates are replete with instances of language play because in these communicative situations "relationships are already established and there is little information to exchange". Tidwell and Walther (2002: 319-20) suggest that "the absence of nonverbal cues, ... identity cues, and temporal characteristics" in CmC may lead to "hyperpersonal" (Walther 1996) or heightened states of intimacy between individuals communicating in this medium. In the case of Astrid and Seamus, it seems that two factors conducive to the occurrence of language play converge: they are boyfriend and girlfriend, communicating in the reduced cues medium of chat. Computerized language play may function as a type of linguistic ritual between Seamus and Astrid in which they simultaneously perform and maintain their relationship as intimates. It is somewhat surprising, therefore, that Seamus engages in language play so frequently in his first chat with his keypal, Katerine, and, as a result, it may appear that he is coming on to her, a possibility that he vehemently denies in his interview. Instead, the institutionalization (and thus legitimization) of chatting with a German woman in class time may represent for Seamus a blurring of his public and private spheres that is difficult for him to disentangle linguistically in his foreign language. Seamus explained in his interview that, other than his brief high school trip to Germany mentioned earlier, his only contact with speakers of German has been his daily electronic exchanges with Astrid. Seamus may therefore use those linguistic practices that have been successful in his previous contact with Germans, i.e. language play, in order to establish a positive rapport with Katerine (see also Baym 1995; Bays 1998).

\section{Foreign language play for presentation of positive face}

One aspect of personal relationship building is the presentation of positive face to one's interlocutor (Scollon and Scollon 2001: 46-7). In other words, a speaker attempts to establish that he or she is a desirable and worthwhile 
(conversational) partner. In $\mathrm{CmD}$ communities researchers have noted that language play may be one means of achieving the presentation of positive face (Aycock 1993; Danet et al. 1998; Raymond 1991: 20). Burnett (2000: 6), for example, explains that an individual's value in virtual communities, which are "defined by their basis in the exchange of texts", may be

manifested at the linguistic level in the playful exchange of texts, through such behaviours as punning, deliberate non-sequitors and other uses of language on a 'nonsensical' level, 'riffing' on particular ideas or phrases or 'memes', or other forms of language play... (italics added)

Through his heavy participation in $\mathrm{CmD}$ communities, Seamus may have learned to use language play as a means by which to present a positive image of himself in the text-only medium of chat and in his web-biography (see Döring 2002 and Turkle 1995 for identity presentation in personal web pages; see also Lam 2000 for online identity presentation in ESL). We know that Seamus values this ability in others because he related in his interview that Katerine's play with Langsamer gave him a "very cool impression of her".

Language learners in other contexts have also pointed toward linguistic ability and verbal agility as desirable traits that contribute to the construction of the positive face of its users. For example, the Polish-speaking main character in Eva Hoffman's (1989) novel, Lost in Translation: Life in a New Language, confesses that she fell in love with and married her Englishspeaking husband because she was "seduced by [his] language". She explains how she hoped that mastering her husband's verbal abilities and "wordplay" would aid her in her reconstruction of her self in her second language, English. In similar fashion, Debi, a 32-year-old English-speaking learner of both German and Spanish, commented in an interview that she was "so attracted" to her Spanish-speaking husband's language that she would "drop everything to listen to him speak Spanish on the phone with his family" (see Belz 2002b: 27). We suggest that Seamus is aware that language play can function as a means to present a positive, desirable image of himself to his interlocutors in chat.

\section{Foreign language play as an index of linguistic multicompetence}

Fowler (1996: 55) notes that "the ultimate process in linguistic creativity would be the formation of a whole new code, a system of new linguistic arrangements encoding a whole new area of knowledge". Even if Seamus does not create a "whole new code" for his personal style of (computer-mediated) (foreign language) communication, he, like Anu and Carl (see pp. 330 and 346), does create a name for the new types of communicative practices that foreign language study has afforded him. In the final entry in his cumulative course portfolio, Seamus notes that he has decided to write "was über mein 
verrücktes Deutsch" ('something about my crazy German') and then reveals that he has created the name Seamusdeutsch to refer to the way that he "spielt herum" 'plays around' with his foreign language. This name is a heteroglossic echo of Seamus' (emerging) linguistic and cultural hybridity of identity in several regards.

First, it contains signs in two languages for two different aspects of his cultural and linguistic identities. His name, Seamus, is an onomastic sign for his (English-speaking) Irish heritage, an important aspect of his self on which he comments numerous times. The German word Deutsch is a sign for the foreign language that he is learning but also for the language and culture of his girlfriend. Both the German language and culture are becoming a major part of his own life through her, and he intends to make them the centerpiece of his future career as a teacher of German, the only academic subject that has ever interested him. Second, Seamus modifies the term Seamusdeutsch with the adjective verrückt 'crazy'. His use of verrückt may be an indication of his awareness that elongated words and seven-word, invented nominal compounds are not the standard, sanctioned discourse of conventional classroom culture; they are representative, however, of his (multilingual) linguistic practices in the culture of cyberspace (see Danet and Herring 2003). Finally, Seamus' use of verrückt serves as a re-voicing of a segment of the name that Astrid creates to refer to him in example 5. It is also a re-voicing of Katerine's assessment of him and his verbal practices in a chat. At one point in this chat, Seamus suddenly produced the elongated word blaaaaaaaaaaaaaaah, which prompted Katerine to ask: "Was heißt das denn jetzt?" ('now what's that supposed to mean?'). When Seamus explained that it does not mean anything, that he was "just making a noise", Katerine concluded "du bist schon ein bisschen verrückt, aber das ist ok. Ich hasse, langweilige Leute!" ('you are really a little bit crazy, but that is ok. I hate boring people'). If Seamus were attempting to present a positive image of himself as a 'fun and crazy guy' through his use of language play, Katerine's assessment of his use of letter elongation in this case appears to indicate that he has succeeded in some small measure.

Belz (2002b: 26) reports the case of Carl, an English-speaking learner of German, Russian, French, and Spanish who creates the terms Carlsprache and Carlolangue as lexical representations of his multilingual thoughts and practices. She argues that these hybridized names for the unique and multilingual language that Carl uses function as textual icons of his growing state of multicompetence. V. Cook (1991: 112) has coined the term 'multicompetence' to refer to the existence of two or more (partial) grammars in the mind of the language learner, a state of affairs that does not necessarily result in communicative inadequacy or deficiency. Instead, he emphasizes the potential (and beneficial) inter-penetration and inter-animation of the multiple linguistic systems in the mind of a multicompetent speaker when he writes that there are "intricate links between the two [or more] language systems in multicompetence: In the mind, the L1 is not insulated from the L2" (Cook 
1999: 193). In his fabrication of the name verrïcktes Seamusdeutsch, Seamus produces a hybridized textual icon for the various (emerging) competencies and identities (English, German, $\mathrm{CmC}$, Irish, and intimate language play) that contribute to the construction and presentation of his self in computermediated discourse (see Danet et al. 1998: 50-1 for the pragmatically hybrid nature of 'nicks' or nicknames in chat culture; see also Bechar-Israeli 1995).

Furthermore, Seamus explained when interviewed how he devised his screen name, FrodoDreiMSM ${ }^{9}$ using a song title "Frodo Three the Mechanical Spirit Man" written by his favorite band, Mr. Blunder, translating the second word of the song title into German, giving him an unusual, anagram-like bilingual screen name, a textual icon of a unique $\mathrm{CmC}$ competent, bilingual identity (see Crystal 2001: 159-61; Bechar-Israeli 1995), which also points toward his musical interests (he is pictured playing the guitar in his webbiography). Online nicknames are iconic of identity play, a form of "online plumage" that "call attention to the person, and to the mask [i.e. the nickname] and its expressive power, imaginativeness, capacity to instill fear, [and] evoke humor" (Danet et al. 1998: 49).

\section{Telecollaborative FLL as a mediator of foreign language play}

\section{Time}

Walther (1996) has noted that everything that happens in face-to-face communication (e.g. personal relationship building) can also happen in $\mathrm{CmC}$, only at a slower rate. The slower pace of $\mathrm{CmC}$ is related to the fact that it takes longer to write than it does to speak. This medium-contingent lengthening of the communicative act may serve to open up an interstitial space in which the language player finds the time that he or she needs to play creatively with the foreign code. In his interview, Seamus explained that $\mathrm{CmC}$ is more conducive to verrücktes Seamusdeutsch than face-to-face communication "because ... when you're on the computer you have that two, three seconds to think of something" (cf. Danet et al. 1998: 44, who state that it is the speed of chat that affords language play). Indeed, communication theorist Susan Herring (1999) has noted that some chatters exploit the disrupted adjacency, turn overlapping, and topic decay caused by the temporal latency in $\mathrm{CmC}$ for the "purposes of play".

\section{Mode of communication}

Many communication theorists have noted that $\mathrm{CmC}$ represents a sort of interstitial space with respect to traditional notions of orality and literacy as well (e.g. Bolter 1991; Crystal 2001; Herring 2002; Walther 1996). Sandbothe (1998) explains that the "appresent presence" of interlocutors in CmC has 
led to a "fluidity" of the distinction between language (i.e. speech) and writing - a state of linguistic affairs that he quite illustratively refers to as the "scriptualization of language" and the "verbalization of writing". According to Sandbothe (1998),

In on-line chat the communicative mode of spoken language is disjoined from the verbal medium and adopted in that of writing ... Conversely writing is disjoined from the typical characteristics of written language. In on-line chat it becomes interactively modelable and contextually situated, a form of writing functioning in much the same way as spoken language.

These transformative tendencies represent a transliteration of sorts, a modal re-semioticization of reality, a moment of transition, a sort of liminoid contact zone (Turner 1982) in which the traditional rules of communicative practice have been suspended with respect to the prototypes of both orality and literacy. This suspension entails a subsequent re-negotiation of the rules of linguistic engagement, and it is in this re-negotiation that one finds the room (and the time) for slippage, artifice, burlesque, farce, gimmick, ruse, and play. For example, Patricia, a German-speaking participant in the same telecollaborative project and, like Katerine, a first-time user of Internet communication tools, engaged in a variety of non-traditional linguistic practices (with respect to the foreign language classroom) which included multilingual punning, rhyming, anagrams, and rampant intersentential codeswitching. On a post-telecollaboration questionnaire, Patricia explicitly stated that her introduction to $\mathrm{CmC}$ facilitated the realization that she could "play around" with communication:

Chatting was fun. During the [telecollaborative] seminar I realized that it is possible to play around with communication. I have the freedom to choose whether I phone, e-mail, write, or chat. For a long time I didn't really understand that since I first had to come to grips with using e-mail and chat... It is nice to observe this learning process. [translation]

Anonymity and deindividuation

Researchers in Internet Studies have discussed intensely the quasi-anonymity afforded by $\mathrm{CmC}$ from essentially two perspectives. Early research (e.g. Dubrovsky, Kiesler and Sethna 1991) argued that the reduced-cues medium of electronic correspondence accounted for the "deindividuation" of the interlocutor and resulted in an inability to form personal relationships in electronic correspondence. This may be the reason why Seamus commented that he could say whatever he wanted to his AIM buddies and not have to worry about when he was "ever going to see them". Later research claimed 
that this same feature fostered the over-attribution of positive qualities to one's interlocutor and could therefore lead to hyperpersonal interaction characterized by heightened levels of intimacy (e.g. Jones 1995; Parks and Floyd 1996; Walther 1996: 5), as may be evidenced in Seamus and Astrid's electronic interaction. We wish to suggest that, in the case of telecollaborative discourse, the reduced-cues medium of $\mathrm{CmC}$ may afford increased uses of private speech (Vygotsky 1978, 1986), i.e. "vocalized" self-directed speech, a multi-functional phenomenon that some researchers see as crucial to foreign language learning (e.g. de Guerrero 1999, 2004; Lantolf 1997, 2000; Lantolf and Yáñez 2003; Ohta 2001). In other words, the "appresent presence" (Sandbothe 1998) of the conversational partner in CmC may license an increase in 'talking to yourself' - a communicative practice that is typically suppressed in the adult in the social presence of others (Kuczaj 1983). Seamus appears to engage in private speech in these data in the case of repeated letters such as sedafdsfsdfdsf which he refers to as "frustration words". Soskin and John (1963) note that private speech occurs, among other things, in moments of cognitive stress. In some $\mathrm{CmD}$ communities it is standard practice to tag certain utterances with the abbreviations "TOL" (thinking out loud) or "TTM" (talking to myself). It may be the case that other aspects of Seamus' language play represent private speech as well; this, however, is a matter for further investigation.

\section{Hybridity of script in the telecollaborative classroom}

Educational linguist Evelyn Hatch has suggested (1992: 89) that the learner's knowledge of what goes on in the foreign language classroom is organized in terms of culturally-contingent scripts (Schank and Abelson 1977). In many locations around the world, this classroom script involves the transmittance of grammatical knowledge from the teacher to the student in the form of information units, the acquisition of which can be uniformly assessed on discrete-point tests, so that the student might communicate with foreignspeaking others (Belz 2001b: 227-8). As a result, foreign language learning is seen as a serious, rule-governed, utilitarian-oriented affair in which the teacher is the ultimate arbiter of foreign language knowledge (G. Cook 2000: 158). Telecollaborative foreign language study flouts learners' script-based expectations of instructed foreign language learning on a number of counts, including the authorization of the teacher as the sole representative of the foreign language and culture (e.g. in telecollaboration, keypals share this role), the centrality of rule-governed grammatical knowledge as a learning goal (Belz 2003: 93; Belz and Kinginger 2003), the monolithic, standardized nature of the foreign language itself (Kinginger 1998), and the tendency to have teacherfronted participation formats (Fitch, cited in Tella 1996: 6).

Just as the scriptualization of language introduces a measure of hybridity into $\mathrm{CmC}$ in terms of the linguistic features of mode (see McCarthy and 
Carter 1994: 3-9), telecollaborative language study affords a hybridity of activity as communicative practices that were previously relegated to the private sphere become institutionalized. As Thorne (2003: 40) notes, "CMC activity often appears to forge a hybridity that allows for an interplay between students' non-academic identities and the discursively constructed institutionalized roles of the classroom". In the case of Seamus, an activity (chatting with people he does not know) that grew out of an adolescent punishment (not being allowed to go out or watch TV) and an activity that he performed in the recesses of his private life (chatting with a German woman) suddenly became sanctioned (even graded) within the four walls of his German classroom. Gee (1999: 22) notes that certain (in his terms) "big-D" Discourses, i.e. "socially accepted associations among ways of using language, of thinking, valuing, acting, and interaction, in the right places and at the right times with the right objects" can meld together to produce "borderland Discourses" which are characterized, at least initially, as liminal or transitional spaces in which the rules of engagement are up for grabs.

Telecollaboration appears to represent such a space for Seamus and may be one reason why language play slips so frequently into his telecollaborative interaction with Katerine. It is unlikely that such play with words would be sanctioned within the linguistic confines of the traditional language classroom where a premium is placed on grammatical accuracy and the approximation of foreign language norms. Seamus realizes that his play is bucking classroom convention when he reports during his interview that he would not have written Kurzbiographie with repeated letters if he had "thought that it would have effected [his] grade". By that point in the semester, he explains, he had already got "the concept of what kind of teacher" his instructor was and realized that, from her perspective, verrücktes Seamusdeutsch might be valued in some way. Yet, the power of the institutionalized, traditional classroom script, ingrained through years of educational socialization, is quite strong, as is evidenced in Seamus' final remark regarding his language play in his cumulative course portfolio: "Schließlich will ich sagen, dass ich nicht mit Deutsch herumspiele, weil ich respektlos bin, sondern wegen meiner Liebe dafür" ('In conclusion I want to say that I don't play around with German out of disrespect for it but rather because of my love for it'). At the end of his interview, Seamus stated that he was looking forward to returning to the traditional classroom in the following semester:

u:::m I think I definitely do better in a traditional class environment . . . it's a lot easier you know . . . I think in the traditional class it feels like I learn German more in the traditional class more German language but probably more German culture in this class ... so it's definitely a change but I'm kinda looking forward to getting back to the regular type of section

Despite the fact that telecollaboration afforded linguistic practices that Seamus enjoyed and even "loved", it appears, as Fowler (1996: 43) suggests, 
that the "dominance of legitimated language continues throughout [his] life". In contradistinction to the classroom described in Gutiérrez, Rymes, and Larson (1995) where the teacher refused to validate students' home knowledge and thus allow an institutional 'counterscript' to emerge and flourish, it was the teacher in this telecollaborative course who sanctioned students' previously acquired $\mathrm{CmC}$ competence and hoped for a counterscript to surface. The hybridity of the telecollaborative classroom, however, seems to have impinged too forcefully on Seamus' private communicative practices and to have flouted too strongly his idealized notions of what foreign language learning should be. In our opinion, however, such commentary is not cause to scrap the telecollaborative enterprise but rather a sober reminder of the need for sound pedagogical intervention designed to harness both the hybridity of telecollaboration and the "inherently playful" aspects of the Internet (Danet et al. 1998: 44; 2001).

\section{Code-switching}

Another factor contributing to the perceived liminality of telecollaboration was the project stipulation that $50 \%$ of the electronic interaction occur in the students' first language (see Paolillo 1996, 2001 for code-switching in chat). This loosening of the L2-only rule prevalent in many foreign language classrooms (V. Cook 2001) may afford the learner the opportunity to experiment with hybridized language play (see Belz 2002a,b,d).

\section{The advanced foreign language learner: a characterization based on language play}

In his description of current language teaching orthodoxies, G. Cook (2000: 149-79) notes that language teaching in recent decades has been both conceptualized and realized as a needs-based enterprise that seeks to develop in the learner the ability to communicate information in a variety of utilitarianoriented contexts (e.g. in a restaurant, on the job) using correct linguistic forms. Gee, however, takes issue with the view that the primary function of language is to transmit information from one interlocutor to another: "If I had to single out a primary function of human language, it would not be one, but the following two: to scaffold the performance of social activities (whether play or work or both) and to scaffold human affiliation within cultures and social groups and institutions" (Gee 1999: 1). As a result, one might argue that advanced proficiency in a language entails, among other things, the ability to use language as a symbolic resource in order to effect membership in social groups and in order to facilitate the performance of social actions within these groups. This competency, at the very least, will consist of an "enhanced awareness" of the "semiotic meaning potential" of 
the foreign language and the enactment of this potential (Belz 2002d: 236). This latter component requires "the ability to manipulate conventional and unconventional structures" (ibid.) in a wide variety of contexts with an array of differing interlocutors and is enabled by a mastery of foreign language forms.

Language play provides an empirically discernible site for the precise description of the mastery and manipulation of foreign language forms and for the (local and pleasurable) enactment of foreign language meaning potential in the case of Seamus. In his creation of the words langsamerin, keinelustheit and Tischleinlichkeit, Seamus displays an awareness and mastery of the rules of morphological derivation in German with respect to both semantics and sequencing (see above). In the case of langsamerin, Seamus attempts to manipulate the conventions of morphological derivation in German by extending the word class of the base of -er suffixation to include adjectives in addition to verbs. As he indicated when interviewed, his purpose in doing so was to create and use a word that described Katerine better than any other word he knows in the local context of his interaction with her. In this way, Seamus exploits the semiotic meaning potential of German for his own locally relevant purposes, which include but are not limited to establishing a positive personal rapport with Katerine. Seamus also demonstrates an enhanced awareness of conventional form-meaning pairings in German in his derivational creation of hundin as a nickname for Katerine a morphological play on her last name. He attempts to manipulate these foreign language signs in order to make his own meaning when he leaves off the umlaut that this derivation would conventionally require (i.e. Hündin) in order to avoid calling Katerine a bitch and thereby insulting her.

Perhaps most importantly for the notion of advanced proficiency, Seamus repeatedly demonstrates that he is aware of the multifunctionality of language, i.e. he knows that it serves as a semiotic resource for much more than the conveyance of informational content. For example, he notes that Katerine's play with words as evidenced by her use of Langsamer gave him a very "cool" impression of her and thereby functioned to establish her positive face in virtual interaction with him. He notes the aesthetic rather than semantic function of words when he states that he likes to make nominal compounds because he likes the way that they both look and sound. In other words, Seamus is able to disentangle the physicality of the code from its meaning in order to engage in linguistic practices that are pleasurable and meaningful perhaps only to him. He further indicates that he is aware of the potential linkage between the sound of words, humor, and the establishment of positive face when he notes that a bunch of German people thought his use of schade marmalade was really funny. ${ }^{10}$ He illustrates that he is aware, however, that such linkages will only work the way he intends them to in particular contexts when he states that he would not utter a funny-sounding goodbyeeеeеeеee to the Dean of the university. Seamus' use of Schlafmütze in conversation with Katerine and his explanation in interview 
that he learned this word from a class text betrays an awareness of the heteroglossic quality of dialogue. The same is true of schade marmalade in that Seamus explains in interview where this word is "from", i.e. he offers a history of his knowledge of its use and function. Although he does not explicitly say so, Seamus' discussion of the history of use of Schlafmütze and schade marmalade may indicate an awareness of the ability of particular phrases to function as temporally cohesive devices across the 'text' of Seamus' linguistic life.

Seamus' awareness of the semiotic meaning potential of German is skillfully enacted in additional ways. His play with derivation and nominal compounding in the context of his chats with his girlfriend, Astrid, may function in the performance of his intimacy with her as well as in the maintenance of his positive face in interaction with her. Seamus demonstrates the multifunctionality of language play itself in his verbal duel with Astrid. In this instance, his play exhibits a competitive, dialogic, game-like quality which is distinct from his more exploratory and monologic uses of it in word-creation. Seamus' (and Astrid's) enactment of these semiotic resources in the context of computer-mediated chat belies an ability to function in German at an advanced level of proficiency.

\section{Conclusion}

In this article we have documented instances of adult foreign language play in the electronic medium and suggested several ways in which these uses may function. Contrary to the typical focus on ideational and/or informational aspects of language use in foreign language study (G. Cook 2000: 149), Seamus' uses of language play tend to cluster in the interpersonal domain of language use: the presentation of positive face, the thrill of linguistic creativity, and the establishment of personal rapport. Thus, it may be the case that language play is particularly instrumental in and reflective of the development of both advanced linguistic competencies and pragmatic competencies. Future research will need to consider ways in which educators may capitalize on foreign language play in pedagogically sound ways for the purposes of personal and linguistic development (for German as a Foreign Language, see Belz 2002d: 228-34; for first language learning, see Cazden 1974, Holmes 2001, Opitz 2000).

Seamus' language play is heavily morphological in nature; there are, however, some examples of graphemic play, but he does not play with the syntax of German, as other learners of German have done (Belz 2002b). Future research will need to investigate whether or not there is a relationship between the aspect of language with which one plays and the medium in which the play occurs. Graphemic play may be more restricted in the electronic medium due to the nature of word processing, but it may also be the case that the medium affords the emergence of a particular kind of 
graphemic play, e.g. emoticons. Similarly, play with more complex levels of grammar may be less likely to occur in synchronous forms of $\mathrm{CmC}$. This is because play with syntax may be more time-consuming than play with orthography or morphology, but, as we have seen above, prolonged response ('sleeping') may be disfavoured in $\mathrm{CmD}$ communities. In other words, the nature of current cultures-of-use in synchronous $\mathrm{CmC}$ may limit play with particular aspects of language.

Finally, we have suggested several ways in which the hybridity of both telecollaboration and $\mathrm{CmC}$ may contribute to the occurrence of foreign language play. Many researchers have noted the rapidity of technological development and the subsequent ephemerality of Internet-based communicative practices. As second-generation Internet communication tools make their way into foreign language classrooms, researchers will need to become increasingly aware of the ways in which new technologies may afford new kinds of language play (Goodwin-Jones 2003: 12), and, most importantly, they will need to diversify the ways in which one might capitalize on these in foreign language learning.

\section{Notes}

1. This project is funded, in part, by a United States Department of Education International Research and Studies Program Grant (CFDA No.: 84.017A).

2. Broner and Tarone (2001: 367) suggest five channel cues for identifying instances of language play. Many of these cues, however, apply only to the spoken medium of interaction (e.g. laughter, shifts in pitch, whispering, volume). As a result, they are not useful in identifying instances of language play in other media (e.g. written language play in literature, advertising, graffiti, the margins of class notes, electronic chat, e-mail), although these additional contexts have proved to be fertile ground for play with language.

3. G. Cook (1996a,b, 1997, 2000), as mentioned in the introduction, does not exemplify the phenomenon of language play with learner-produced data (see Belz 2001 for a detailed review of G. Cook 2000). Crystal (1998) approaches the topic of language play from a more popularized L1 perspective, although he does briefly consider the relation of language play to language learning.

4. Tarone's use of the term ludic is problematic because it is quite different from Caillois' (1969) use of the term ludus. Tarone uses ludic to refer to fun and amusement, while Caillois uses ludus to indicate rule-orientation. Caillois (1969) figures prominently in G. Cook (2000), a researcher on whom Tarone draws extensively.

5. In some cases, the American students were able to chat in class with their German partners, despite the fact that the two courses did not overlap temporally. This occurred when the German partners agreed to be online outside of their class time when the Americans were online during their respective class period.

6. In order for this example to make sense, this learner's last name is reported; however, her first name is a pseudonym. Hund is a common last name in Germany. 
7. Chris is a 27-year-old English-speaking learner of German in a fifth-semester German course at a public institution on the West coast of the United States (see Belz 2002a).

8. Of course, it may also be the case that learners "play around" with forms that they have not yet fully mastered in order to create new forms, a risky and perhaps therefore alluring activity. This may be what happened in Seamus' production of hundin, which backfired quite forcefully.

9. Seamus' screen name has been changed to protect his identity, but the principles on which it was formed remain the same.

10. We are grateful to Jon Ole Askedal for pointing out to us that learners of German also typically find the sound of the ach-Laut $[x]$ and the placement of the conjugated verb in the dependent clause to be humorous.

\section{References}

Appel, M.C. (1999) Tandem language learning by e-mail: some basic principles and a case study. (Occasional Paper No. 54.) Dublin: Centre for Language and Communication Studies.

Aycock, A. (1993) Virtual play: Baudrillard online. Electronic Journal of Virtual Culture 1.7. Available online at http://www.uta.edu/english/apt/collab/texts/ virtualplay.html.

Bakhtin, M. (1981) The dialogic imagination [M. Holquist (ed.), C. Emerson and M. Holquist, transl.]. Austin, TX: University of Texas Press.

Barthes, R. (1974) S/Z [R. Miller, transl.]. New York: Hill and Wang.

Baym, N. (1995) The performance of humor in computer-mediated communication. Journal of Computer-Mediated Communication 1.2. Available online at http:// www.ascusc.org/jcmc/vol1/issue2/baym.html.

Bays, H. (1998) Framing and face in Internet exchanges: a socio-cognitive approach. Linguistik Online 1.1: 1-11.

Bechar-Israeli, H. (1995) From <Bonehead $>$ to $<$ cLoNehEAd $>$ : nicknames, play and identity on Internet relay chat. Journal of Computer-mediated Communication 1.2. Available online as http://www.ascusc.org/jcmc/vol1/issue2/bechar.html.

Belz, J.A. (1997a) Language use as an index of self-in-transition: evidence from multilingual texts. Paper presented at Cornell University, Ithaca, New York.

- (1997b) Discourse analysis at the cultural faultline: capitalizing on the multilingual reality of language study. Paper presented at the American Association for Applied Linguistics, Orlando, Florida.

- (2000) Language play. Colloquium at the American Association for Applied Linguistics, Vancouver, Canada.

- (2001a) Review of Language Play, Language Learning by Guy Cook. Applied Linguistics 22: 129-34.

- (2001b) Institutional and individual dimensions of transatlantic group work in network-based language teaching. ReCALL 13.2: 213-31.

- (2002a) The myth of the deficient communicator. Language Teaching Research 6.1: $59-82$.

- (2002b) Second language play as a representation of the multicompetent self in foreign language study. Journal for Language, Identity, and Education 1.1: 13-39.

(C) Blackwell Publishing Ltd. 2004 


\section{6 - Julie A. Belz and Jonathon Reinhardt}

- (2002c) Social dimensions of telecollaborative foreign language study. Language Learning and Technology 6.1: 61-80.

- (2002d) Identity, deficiency, and L1 use in foreign language study. In C. Blyth (ed.), The sociolinguistics of foreign language classrooms: contributions of the native, near-native and the non-native speaker. Boston, MA: Heinle and Heinle. 209-50.

- (2003) Linguistic perspectives on the development of intercultural competence in telecollaboration. Language Learning and Technology 7.2: 68-117.

- (in preparation) Foreign language play and the discursive construction of identity. New Haven, CT/London: Yale University Press.

- and C. Kinginger (2002) The cross-linguistic development of address form use in telecollaborative language learning: two case studies. Canadian Modern Language Review/Revue canadienne des langues vivantes 59.2: 189-214.

- and C. Kinginger (2003) Discourse options and the development of pragmatic competence by classroom learners of German: the case of address forms. Language Learning 53.4: 591-647.

- and A. Müller-Hartmann (2002) Deutsch-amerikanische Telekollaboration im Fremdsprachenunterricht - Lernende im Kreuzfeuer der institutionellen Zwänge. Die Unterrichtspraxis/Teaching German 35.1: 68-78.

Bialystok, E. (1998) Coming of age in applied linguistics. Language Learning 48.4: 497518.

Bolinger, D. (1975) Aspects of language (2nd edition). New York: Harcourt, Brace, and Javonovich.

Bolter, J. (1991) Writing space: the computer, hypertext, and the history of writing. Hillsdale, NJ: Lawrence Erlbaum.

Bongartz, C. and M. Schneider (2003) Linguistic development in social contexts: a study of two brothers learning German. Modern Language Journal 87.1: 13-37.

Broner, M. and E. Tarone (2001) Is it fun? Language play in a fifth-grade Spanish immersion classroom. Modern Language Journal 85.3: 363-79.

Brown, P. and S. Levinson (1987) Politeness: some universals in language usage. New York: Cambridge University Press.

Burnett, G. (2000) Information exchange in virtual communities: a typology. Information Research 5.4. Available online at http://InformationR.net/ir/5-4/ paper82a.html.

Byrnes, H. (2001) Reconsidering graduate students' education as teachers: it takes a department! Modern Language Journal 85.4: 512-30.

— and H. Maxim (2004) Advanced foreign language learning: a challenge to college programs. Boston: Heinle.

Caillois, R. (1969) The structure and classification of games. In J.W. Loy and S. Kenyon (eds.), Sport, culture, and society: a reader on the sociology of sport. London: Macmillan. (Original work published 1955.)

Cazden, C. (1974) Play and metalinguistic awareness: one dimension of language experience. Urban Review 7.1: 28-39.

Chiaro, D. (1992) The language of jokes. Analysing verbal play. London: Routledge.

Cook, G. (1996a) Language play in English. In J. Maybin and N. Mercer (eds.), Using English: from conversation to canon. London and New York: Routledge. 198-234.

- (1996b) Language play in advertisements: some implications for applied linguistics. In D. Graddol and J. Swann (eds.), Evaluating language: papers from the annual meeting of the British Association for Applied Linguistics. Clevedon: British Association for Applied Linguistics. 102-16. 
- (1997) Language play, language learning. ELT Journal 51.3: 224-31.

- (2000) Language play, language learning. Oxford University Press.

Cook, V. (1991) The poverty of stimulus argument and multicompetence. Second Language Research 7.2: 103-17.

- (1992) Evidence for multicompetence. Language Learning 42.4: 557-91.

- (1995) Multi-competence and the learning of many languages. Language, Culture and Curriculum 8.2: 93-8.

- (1999) Going beyond the native speaker in language teaching. TESOL Quarterly 33.2: 185-209.

- (2001) Using the first language in the classroom. The Canadian Modern Language Review/La revue canadienne des langues vivantes 57.3: 412-23.

Crystal, D. (1998) Language play. London: Penguin.

- (2001) Language and the Internet. Cambridge University Press.

Danet, B. (2001) Cyberpl@y: communicating online. Oxford: Berg.

- and S. Herring (eds.) (2003) The multilingual Internet: language, culture and communication in instant messaging, email and chat. Special issue, Journal of Computer-Mediated Communication 9.1. Available online at http:/ /www.ascusc.org/ jcmc/vol9/issue1/.

- L. Ruedenberg and Y. Rosenbaum-Tamari (1998) Hmmm ... where's that smoke coming from? Writing, play and performance on Internet relay chat. In F. Sudweeks, M. McLaughlin and S. Rafaeli (eds.), Network and netplay: virtual groups on the Internet. Cambridge, MA: MIT Press. 41-74.

de Guerrero, M.C.M. (1999) Inner speech as mental rehearsal: the case of advanced L2 learners. Issues in Applied Linguistics 10: 27-55.

- (2004) Early stages of L2 inner speech development: what verbal reports suggest. International Journal of Applied Linguistics 14.1.

Delisle, H. (1986) Intimacy, solidarity, and distance: the pronouns of address in German. Die Unterrichtspraxis 19.1: 4-15.

Döring, N. (2002) Personal home pages on the Web: a review of research. Journal of Computer-Mediated Communication 7.3. Available online at http://www.ascusc.org/ jcmc/vol7/issue3/doering.html.

Drosdowski, G. (ed.) (1984) Duden: Grammatik der deutschen Gegenwartssprache. Bibliographisches Institut Mannheim: Dudenverlag.

Dubrovsky, V.J., S. Kiesler and B.N. Sethna (1991) The equalization phenomenon: status effects in computer-mediated and face-to-face decision-making groups. Human Computer Interaction 6: 119-46.

Durrell, M. (2002) Hammer's German grammar and usage (4th edition). Chicago: McGraw-Hill.

Ely, R. and A. McCabe (1994) The language play of kindergarten children. First Language 14: 19-35.

Firth, A. and J. Wagner (1997) On discourse, communication and (some) fundamental concepts in FLA research. The Modern Language Journal 81: 285-300.

Fowler, R. (1996) Linguistic criticism (2nd edition). Oxford University Press.

Frawley, W. (1997) Vygotsky and cognitive science: language and the unification of the social and computational mind. Cambridge, MA: Harvard University Press.

Fromberg, D. (1999) A review of research on play. In C. Seefeldt (ed.), The early childhood curriculum: current findings in theory and practice. New York: Teachers College Press. 27-53.

Fry, W. (1963) Sweet madness. Palo Alto, CA: Pacific Books.

(C) Blackwell Publishing Ltd. 2004 
Furstenberg, G., S. Levet, K. English and K. Maillet (2001) Giving a virtual voice to the silent language of culture: the Cultura project. Language Learning and Technology 5.1: 55-102.

Garvey, C. (1977) Play. Cambridge, MA: Harvard University Press.

Gee, J. (1999) An introduction to discourse analysis: theory and method. London: Routledge.

Goodwin-Jones, B. (2003) Blogs and wikis: environments for on-line collaboration. Language Learning and Technology 7.2: 12-16.

Gossen, G. (1976) Verbal duelling in Chamula. In B. Kirschenblatt-Gimblett (ed.), Speech play. Philadelphia: University of Pennsylvania Press. $x-y$.

Gutiérrez, K., P. Baquedano-López and H. Álvarez (2001) Literacy as hybridity: moving beyond bilingualism in urban classrooms. In M. de la Luz Reyes and J. Halcón (eds.), The best for our children: critical perspectives on literacy for Latino students. New York: Teachers College Press. 122-41.

—, P. Baquedano-López and C. Tejeda (1999) Rethinking diversity: hybridity and hybrid language practices in the third space. Mind, Culture, and Activity 6.4: 286303.

— , B. Rymes and J. Larson (1995) Script, counterscript, and underlife in the classroom: James Brown versus Brown v. Board of Education. Harvard Educational Review 65.3: $445-471$.

Halliday, M.A.K. (1978) Language as social semiotic: the social interpretation of language and meaning. London: Edward Arnold.

- (1993) Towards a language-based theory of learning. Linguistics and Education 5: 93-116.

- (1994) An introduction to functional grammar (2nd edition). London: Edward Arnold.

Härtling, P. (1990) Ben loves Anna [J.H. Auerbach, transl.]. Woodstock, NY: Overlook Press.

— (1997) [1977] Ben liebt Anna [Ben Loves Anna] (2nd edition). Weinheim, Germany: Beltz Verlag.

Hatch, E. (1992) Discourse and language education. Cambridge University Press.

Herring, S. (1999) Interactional coherence in CMC. Journal of Computer-Mediated Communication 4.4. Available online at http://www.ascusc.org/jcmc/vol4/issue4/ herring.html.

- (2002) Computer-mediated communication on the Internet. In B. Cronin (ed.), Annual Review of Information and Science Technology. Medford, NJ: Information Today, Inc. 109-68.

- (2003) Computer-mediated discourse analysis: an approach to researching online behavior. In S.A. Barab, R. Kling and J.H. Gray (eds.), Designing for virtual communities in the service of learning. New York: Cambridge University Press.

Hoffman, E. (1989) Lost in translation: a life in a new language. London: Minerva.

Holmes, L. (2001) Inventive language play grows up: exploiting students' linguistic play to help them understand and shape their learning. New Advocate 14.4: 41315.

Honeycutt, L. (2001) Comparing e-mail and synchronous conferencing in online peer response. Written Communication 18.1: 26-60.

Huizinga, J. (1949) Homo ludens: a study of the play element in culture [R. Hull, transl.]. New York: Roy.

Ivanic, R. (1998) Writing and identity: the discoursal construction of identity in academic writing. Amsterdam/Philadelphia: John Benjamins. 
Jakobson, R. and L. Waugh (1987) The sound shape of language (2nd edition). Bloomington, IN: Indiana University Press.

John-Steiner, V.P. and P. Tatter (1983) An interactionist model of language development. In B. Bain (ed.), The sociogenesis of language and human conduct. New York: Plenum. 79-97.

Jones, S. (1995) Cybersociety: computer-mediated communication and community. Thousand Oaks, CA.: Sage.

Kinginger, C. (1998) Videoconferencing as access to spoken French. The Modern Language Journal 82.4: 501-13.

- (2002a) Communicative foreign language teaching through telecollaboration. In O. St. John, K. van Esch and E. Schalkwijk (eds.), New insights into foreign language learning and teaching. Frankfurt: Peter Lang Verlag.

- (2002b) Alice doesn't live here anymore: Foreign language learning and renegotiated identity. In A. Pavlenko and A. Blackledge (eds.), Negotiation of identities in multilingual contexts. Multilingual Matters.

- (2002c) Defining the zone of proximal development in U.S. foreign language education. Applied Linguistics 23.2: 240-61.

- , A. Gourvès-Hayward and V. Simpson (1999) A tele-collaborative course on FrenchAmerican intercultural communication. French Review 72.5: 853-66.

Kötter, M. (2003) Negotiation of meaning and code-switching in online tandems. Language Learning and Technology 7.2: 145-72. Available online at http:// llt.msu.edu/vol7num2/kotter/default.html.

Kramsch, C. (1993) Context and culture in language teaching. Oxford University Press.

Krashen, S. (1981) Second language acquisition and second language learning. New York: Pergamon Press.

Kuczaj, S. (1983) Crib speech and language play: developmental implications. New York: Springer.

Lakoff, G. (1987) Women, fire, and dangerous things. What categories reveal about the mind. University of Chicago Press.

Lam, W.S.E. (2000) L2 literacy and the design of the self: a case study of a teenager writing on the Internet. TESOL Quarterly 34.3: 457-82.

Lantolf, J. (1997) The function of language play in the acquisition of L2 Spanish. In W. Glass and A.T. Leroux-Perez (eds.), Contemporary perspectives on the acquisition of Spanish. Somerville, MA: Cascadilla Press. 3-24.

- (2000) Language learning as fun and games: the role of language play in SLA. Paper presented at the American Association for Applied Linguistics, Vancouver, Canada.

- (2002). Sociocultural theory and second language acquisition. In R. Kaplan (ed.), The Oxford handbook of applied linguistics. Oxford University Press. 10414.

— and G. Appel (eds.) (1994) Vygotskian approaches to second language research. Norwood, NJ: Ablex.

— and M. Yáñez (2003) Talking yourself into Spanish: intrapersonal communication and second language learning. Hispania 86.1: 97-109.

Layder, D. (1993) New strategies in social research. Cambridge, UK: Polity Press.

Leaver, B.L. and B. Shekhtman (eds.) (2002) Developing professional-level language proficiency. Cambridge University Press.

Leung, C., R. Harris and B. Rampton (1997) The idealised native speaker, reified ethnicities, and classroom realities. TESOL Quarterly 31.3: 543-60. 
MacWhinney, B. (1985) Hungarian language acquisition. In Slobin, D. (ed.), The crosslinguistic study of language acquisition. Hillsdale, NJ: Erlbaum. 1069-155.

Müller-Hartmann, A. (2000) Wenn sich die Lehrenden nicht verstehen, wie sollen sich dann die Lernenden verstehen? Fragen nach der Rolle der Lehrenden in global vernetzten Klassenräumen. In L. Bredella, H. Christ and M.K. Legutke (eds.), Fremdverstehen zwischen Theorie und Praxis. Narr: Tübingen. 275-301.

Nilsen, D. (1981) Bilingual and bidialectical language play. Rocky Mountain Review of Language and Literature 35.2: 128-37.

Oberle, B. (1990) Das System der Ableitungen auf-heit, -keit und -igkeit in der deutschen Gegenwartssprache. Heidelberg: Carl Winter Universitätsverlag.

O'Dowd, R. (2003) Understanding the 'other' side: intercultural learning in a SpanishEnglish e-mail exchange. Language Learning and Technology 7.2: 118-44. Available online at http://llt.msu.edu/vol7num2/odowd/default.html.

Ohta, A. (2001) Second language acquisition processes in the classroom: learning Japanese. Mahwah, NJ: Lawrence Erlbaum.

Opie, I. and P. Opie (1955) The Oxford nursery rhyme book. Oxford University Press.

Opitz, M. (2000) Rhymes and reasons: literature and language play for phonological awareness. Portsmouth, NH: Heinemann.

Paolillo, J. (1996) Language choice on soc.culture.punjab. Electronic Journal of Communication/La Revue Electronique de Communication 6.3.

- (1999) The virtual speech community: social network and language variation on IRC. Journal of Computer-Mediated Communication 4.4: 1-13.

- (2001) Language variation on Internet Relay Chat: a social network. Journal of Sociolinguistics 5.2: 180-213.

Parks, R. and K. Floyd (1996) Making friends in cyberspace. Journal of Communication 23: 409-25.

Peck, S. (1980) Language play in child second language acquisition. In D. LarsenFreeman (ed.), Discourse analysis in second language research. Rowley, MA: Newbury House. 154-64.

Rampton, B. (1995) Crossing: language and ethnicity among adolescents. London/New York: Longman.

- (1999) Deutsch in Inner London and the animation of an instructed foreign language. Journal of Sociolinguistics 3.4: 480-504.

Raymond, E. (1991) The new hackers' dictionary [with assistance and illustrations by G.L. Steele, Jr.]. Cambridge, MA: MIT Press.

Sandbothe, M. (1998) Media temporalities on the Internet: philosophy of time and media with Derrida and Rorty. Journal of Computer-mediated Communication 4.2. Available online at http://www.ascucs.org./jcmc/vol4/issue2/ sandbothe.html.

Saville-Troike, M. (1988) Private speech: evidence for second language learning strategies during the 'silent period'. Journal of Child Language 15: 567-90.

Schank, R. and R. Abelson (1977) Scripts, plans, goals, and understandings. Hillsdale, NJ: Lawrence Erlbaum.

Scollon, R. and S.W. Scollon (2001) Intercultural communication: a discourse approach. Oxford: Blackwell.

Simpson, P. (1997) Language through literature. London/New York: Routledge.

Soskin, W. and V. John (1963) The study of spontaneous talk. In R. Barker (ed.), The stream of behavior: explorations of its structure and context. New York: Appleton Century Crofts. 228-81. 
Sullivan, P. (2000) Playfulness as mediation in communicative language teaching in a Vietnamese classroom. In J.P. Lantolf, Sociocultural theory and second language learning. Oxford University Press. 115-31.

Swain, M. (1995) Three functions of output in second language learning. In G. Cook and B. Siedlhofer (ed.), Principles and practices in applied linguistics. Oxford University Press. 125-44.

Tarone, E. (2000) Getting serious about language play: language play, interlanguage variation, and second-language acquisition. In M. Anderson, C. Klee, F. Morris, B. Swierzbin and E. Tarone (ed.), The interaction of social and cognitive factors in SLA. Proceedings of the 1999 Second Language Research Forum. Somerville, NJ: Cascadilla Press. 31-54.

- and G.-Q. Liu (1995) Situational context, variation, and second language acquisition theory. In G. Cook and B. Seidlhofer (eds.), Principles and practices in applied linguistics. Oxford University Press. 107-24.

Tella, S. (1996) Foreign languages and modern technology: harmony or hell? In M. Warschauer (ed.), Telecollaboration in foreign language learning. Proceedings of the Hawai'i Symposium. University of Hawai'i Press. 3-17.

Thorne, S. (2003) Artifacts and cultures-of-use in intercultural communication. Language Learning and Technology 7.2: 38-67.

Tidwell, L. and J. Walther (2002) Computer-mediated communication effects on disclosure, impressions, and interpersonal evaluations: getting to know one another a bit at a time. Human Communication Research 28.3: 317-48.

Tomasello, M. (1999) The cultural origins of human cognition. Cambridge, MA: Harvard University Press.

Turkle, S. (1995) Life on the screen: identity in the age of the Internet. New York: Simon and Schuster.

Turner, V. (1982) From ritual to theatre: the human seriousness of play. New York: Performing Arts Journal Publications.

von der Emde, S., J. Schneider and M. Kötter (2001) Technically speaking: transforming language learning through virtual learning environments (MOOs). Modern Language Journal 85: 210-25.

Vygotsky, L.S. (1978) Mind in society: the development of higher psychological processes. Cambridge, MA: Harvard University Press.

- (1986) Thought and language. Cambridge, MA: The MIT Press.

Walther, J. (1996) Computer-mediated communication: impersonal, interpersonal, and hyperpersonal interaction. Communication Research 23.1: 3-43.

Warner, C.N. (2004) It's just a game, right? Types of play in foreign language CMC. Language Learning and Technology 8.2: 69-87.

Warschauer, M. (1996) Telecollaboration in foreign language learning. University of Hawaii Press.

Wellman, B. and M. Gulia (1999) Virtual communities as communities. In M. Smith and P. Kollock (eds.), Communities in cyberspace. London: Routledge.

Weir, R. (1962) Language in the crib. The Hague: Mouton.

Widdowson, H. (1992) Practical stylistics: an approach to poetry. Oxford University Press.

Woodson, J. (1998) If you come softly. New York: Penguin.

[Received 10/5/03; revised 16/7/04]

(C) Blackwell Publishing Ltd. 2004 
362 Julie A. Belz and Jonathon Reinhardt

Julie A. Belz

Pennsylvania State University

Dept. of Germanic and Slavic Languages and Literatures

311 Burrowes Building

University Park, Pennsylvania 16802

USA

e-mail: jab63@psu.edu

Jonathon Reinhardt

Pennsylvania State University

Linguistics and Applied Language Studies

305 Sparks Building

University Park, Pennsylvania 16802

USA

e-mail: jsr199@psu.edu 